\title{
Effect of Different Photovoltaic Materials on Energetic and Exergetic Performance of Photovoltaic Thermal Arrays
}

\author{
C. S. Rajoria ${ }^{1}$, Pankaj Kumar Gupta ${ }^{1}$, Sanjay Agrawal ${ }^{2}$, G. N. Tiwari ${ }^{3}$ and D. Singh ${ }^{1}$ \\ ${ }^{1}$ Government Engineering College Bikaner, Pugal Road Bikaner-334004 \\ ${ }^{2}$ School of Engineering \& Technology, IGNOU, New Delhi, India \\ ${ }^{3}$ Centre for Energy Studies, Indian Institute of Technology Delhi, Hauz Khas, New Delhi-110016
}

\begin{abstract}
The study presents the effect of packing factor of Photovoltaic (PV) module on the room temperature, cell temperature and efficiency of a proposed Building Integrated Semi-transparent Photovoltaic Thermal (BiSPVT) and Building Integrated Opaque Photovoltaic Thermal (BiOPVT) systems with duct mounted on the roof of the building. Different PV materials like mono-crystalline silicon (m-Si), amorphous silicon (a-Si), poly-crystalline silicon (p-Si), cadmium telluride (CdTe), copper indium selenide (CIS) and hetero-junction with intrinsic thin layer (HIT) have been considered in the analysis under the cold climatic condition of India. Since Srinagar (India) has the cold climatic condition, therefore, its climatic data has been considered in the present analysis.
\end{abstract}

\section{Introduction}

The current energy scenario is gradually shifting towards non-conventional sources of energy and is going to be a main substitute for fossil fuels in the coming years for their clean and renewable nature. The PV technology is gathering fast momentum and would soon penetrate into the mainstream. So far about $85 \%$ of the PV market concerns mono- and poly-crystalline silicon modules (mor p-Si) [1] and most of the researchers carried out studies on BIPVT systems by considering the same PV modules. An increase in building energy efficiency by using the PV modules integrated on an office building has been thoroughly investigated [2]. Similar research has been conducted showing a significant gain in energy efficiency [3]. The study of temperature profile of photovoltaic (PV) module in a non-steady state condition with respect to time has been investigated by [4]. The overall electrical efficiency of the PV module can be increased by increasing the packing factor $(\mathrm{PF})$ and decreasing the temperature of the PV module. The effect of packing factor on the electrical and thermal efficiencies of a vertically mounted hybrid photovoltaic water heating system has been investigated by various researchers $[5,6,7]$.

Mono silicon (m-Si) modules are highly efficient but manufacturing process is slow and requires highly skilled operators. Manufacturing of poly silicon (p-Si) modules is simpler but the modules are less efficient. Shortage and high price of silicon PV modules are the main reasons for many solar cell manufacturers to seek alternative raw materials like thin film and multi junction technologies, [8].The present study extends the research for other type of $\mathrm{PV}$ modules (i) $\mathrm{m}$-Si, (ii) p-Si, (iii) amorphous silicon (a-Si), (iv) cadmium telluride (CdTe), (v) copper indium gallium diselenide (CIGS), and (vi) a heterojunction comprised of a thin a-Si PV cell on top of acrystalline silicon (c-Si) cell (HIT), [9,10]. In m-Si and p-Si, packing factor of a PV module can be varied by varying the area of PV cells for a given area of PV module, which has been shown in Figure 1 (a) and (b). In Figure 1 (a), there are 36 cells, each having an area of $0.0139 \mathrm{~m}^{2}$ for a given area of PV module. On the other side, in Figure 1 (b), each cell area is half of $0.0139 \mathrm{~m}^{2}$ for the same area of PV module and therefore, increases the non-packing area i.e. decreases packing factor. However, in case of thin film PV, the packing factor can be varied according to the design e.g. as per need the area of thin filmed PV and glass can be arranged in an alternate fashion to allow solar radiation to pass through the glass area, as shown in Figure 1 (c). In this paper different PV materials have been analyzed to find the effect of different packing factor on the performance of BiSPVT system integrated to roof, for with air duct.

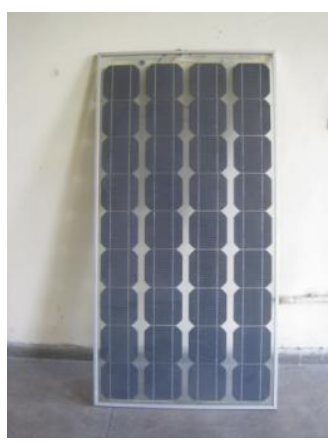

(a)

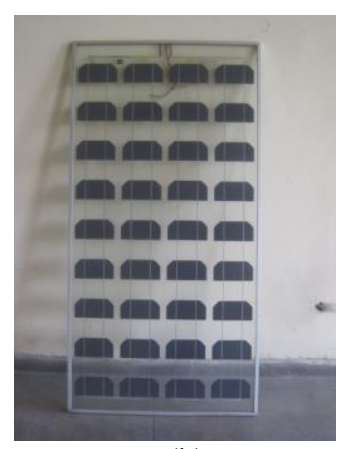

(b) 


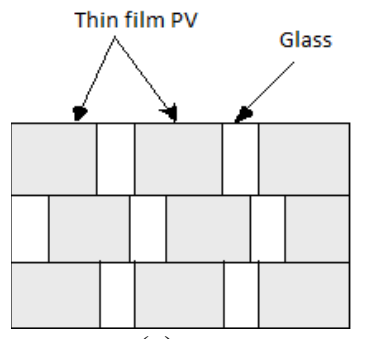

(c)

Figure 1. (a): Photograph of a $75 \mathrm{~W}, \mathrm{PV}$ module with a cell area of $0.0139 \mathrm{~m}^{2}$ (b) Photograph of a $37 \mathrm{~W}$, PV module with a cell area of $0.0069 \mathrm{~m}^{2}$ (c) Proposed design of thin film PV with glass.

\section{Identification of problem}

Semi-transparent PV module

Solar radiation
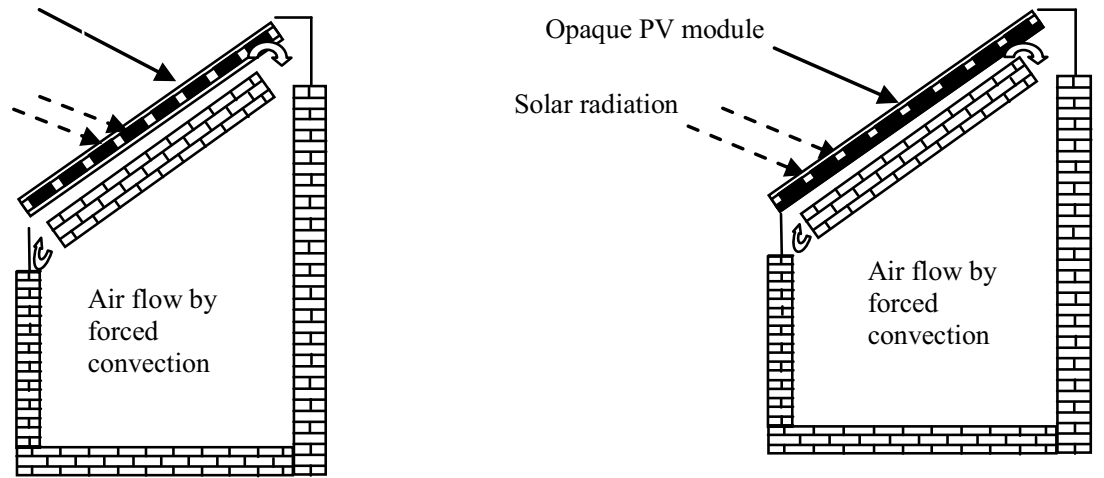

Figure 2. (a): Cross-section view of a building integrated semi-transparent photovoltaic thermal (BiSPVT) system with air duct and integrated to roof a room. (b) Cross-section view of building integrated opaque photovoltaic thermal (BiOPVT) system with air duct and integrated to roof a room.
Table 1. Values of module efficiency and electrical efficiency temperature coefficient for different PV modules.

\begin{tabular}{|l|l|l|}
\hline $\begin{array}{l}\text { Type of PV } \\
\text { module }\end{array}$ & $\begin{array}{l}\text { Module efficiency } \\
\text { STC }(\%) \eta_{r e f, P V, m}\end{array}$ & $\begin{array}{l}\text { Electrical efficiency } \\
\text { temp. coefficient \% } \\
\left(\beta_{r e f, P V, m}\right)\end{array}$ \\
\hline $\mathrm{m}-\mathrm{Si}$ & 13.5 & -0.40 \\
$\mathrm{a}-\mathrm{Si}$ & 6.3 & -0.26 \\
$\mathrm{p}-\mathrm{Si}$ & 11.6 & -0.40 \\
$\mathrm{CdTe}$ & 6.9 & -0.20 \\
$\mathrm{CIS}$ & 8.2 & -0.45 \\
$\mathrm{HIT}$ & 17.0 & -0.33 \\
\hline
\end{tabular}

\subsection{For semi-transparent PV module}

Using expression given by [11], energy balance equation of solar cell as shown in Fig. 2 (a) is,

$$
\alpha_{c} \tau_{g} \beta_{c} I(t) b d x=\left[U_{t c, a}\left(T_{c}-T_{a}\right)+U_{T c, f}\left(T_{c}-T_{f}\right)\right] b d x+\eta_{P V, m} I(t) b d x
$$

where, $\alpha, \beta, \eta$ and $\tau$ are $=$ absorptivity, packing factor, efficiency and transmissivity respectively; while subscripts $a=$ ambient; $b s=$ back surface; $c=$ solar cell; eff=effective; $f=$ fluid (air); $f_{i}=$ inlet fluid; $f_{o}=$ outgoing fluid; $g=$ glass; $L=$ length; $T=\quad$ tedlar; $t c=$ tedlar to cell the energy balance equation of blackened absorber roof is

$$
\alpha_{p}\left(1-\beta_{c}\right) \tau_{g}^{2} I(t) b d x=\left[h_{p, f}\left(T_{p}-T_{f}\right)+U_{p, r}\left(T_{p}-T_{r}\right)\right] b d x
$$

In the present study, the proposed design of BiSPVT and BiOPVT system integrated to roof, with the provision of air duct as shown in Figures 2 (a) - (b) respectively has been considered for determining the effect of packing factors $(0.42,0.62$, and 0.83$)$ of PV for different PV materials as mentioned in Table 1 .

\subsection{Thermal modelling}

Basic heat transfer equations have been used to write the energy balance of the proposed systems

Energy balance equation for BiSPVT and BiOPVT system integrated to roof with air duct (Fig. 2 (a) and (b)) the energy balance equation for air flowing through air duct is

$$
\dot{m}_{f} \mathcal{c}_{f} \frac{d T_{f}}{d x} d x=\left[h_{p, f}\left(T_{p}-T_{f}\right)+U_{T c, f}\left(T_{c}-T_{f}\right)\right] b d x
$$

Eqs. (2) and (3) are for BiSPVT and BiOPVT system integrated to roof considered by [12].

Energy balance equation for room air temperature is

$\dot{m}_{f} c_{f}\left(T_{f o}-T_{r}\right)+A_{w} U_{w}\left(\overline{T_{f}}-T_{r}\right)=M_{a} C_{a} \frac{d T_{r}}{d t}+(U A)_{t}\left(T_{r}-T_{a}\right)+0.33 N V\left(T_{r}-T_{a}\right)$

Integrating and applying initial conditions at $\left.T_{f}\right|_{x=0}$,

$T_{f}=T_{f i}$ and at $\left.T_{f}\right|_{x=L}, T_{f}=T_{f o}$, we get

$$
\begin{gathered}
\overline{T_{f}}=\frac{1}{U_{L, G-G}}\left[(\alpha \tau)_{G-G, e f f} I(t)+\left(U_{L, G-G}-U_{T}\right) T_{a}+U_{T} T_{r}\right]\left(1-\frac{1-\exp \left(\frac{-U_{L, G-G} b L}{\dot{m}_{f} c_{f}}\right)}{\frac{U_{L, G-G} b L}{\dot{m}_{f} c_{f}}}\right)+ \\
T_{r} \frac{1-\exp \left(\frac{-U_{L, G-G} b L}{\dot{m}_{f} c_{f}}\right)}{\frac{U_{L, G-G} b L}{\dot{m}_{f} c_{f}}}
\end{gathered}
$$

Using Eqs. (5) and (6) in Eq. (4), we have

$$
\frac{d T_{r}}{d t}+a T_{r}=f(t)
$$


where, $a=\frac{\left[\left(A F_{r}+A F_{r w}\right)\left(U_{L, G-G}-U_{T}\right)+(U A)_{t}+0.33 N V\right]}{M_{a} C_{a}}$

$f(t)=\frac{\left(A F_{r}+A F_{r w}\right)(\alpha \tau)_{G-G, e f f} I(t)}{M_{a} C_{a}}+\frac{\left[\left(A F_{r}+A F_{r w}\right)\left(U_{L, G-G}-U_{T}\right)+(U A)_{t}+0.33 N V\right] T_{a}}{M_{a} C_{a}}$

Solution of Eq. (6) is obtained by integrating and applying initial condition at time $\mathrm{t}=0, T_{r}=T_{r i}$

$$
T_{r}=\frac{f(t)}{a}(1-\exp (-a t))+T_{r i} \exp (-a t)
$$

The above equation can be computed for any numerical values of $I(t)$, and $T_{a}$ for a given climatic condition.

\section{Results and Discussion}

Fig. 4 shows the effect of packing factor on hourly variation of module efficiency, module temperature and room temperature for $\mathrm{m}$-Si module for a day for BiSPVT system integrated to roof with duct and without duct. It is observed that decrease in packing factor from 0.83 to 0.42 decreases the temperature of module from $40.00{ }^{\circ} \mathrm{C}$ to $24.00{ }^{\circ} \mathrm{C}$ which increases the module efficiency from $12.8 \%$ to $13.6 \%$ and room temperature from $17.60{ }^{\circ} \mathrm{C}$ to $26.20{ }^{\circ} \mathrm{C}$.

The observed values of maximum room and cell temperature and efficiency for different packing factors and different PV modules have been tabulated in Table 2 .

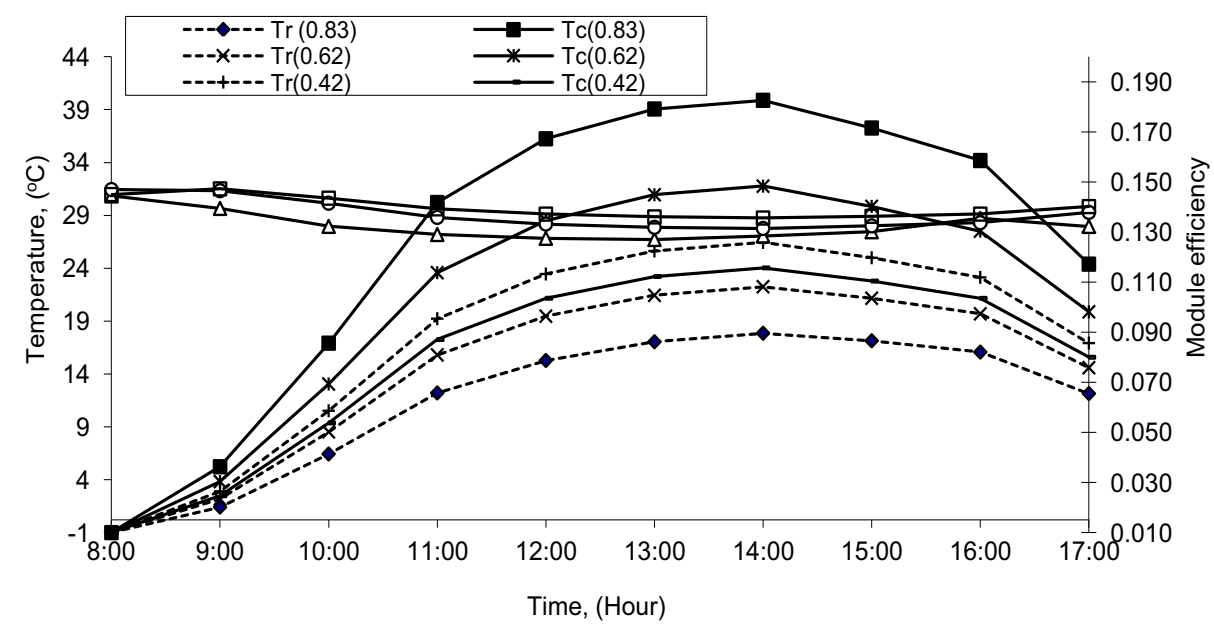

Figure 3. Hourly variation of module efficiency, module temperature and room temperature for different packing factor for $\mathrm{m}-\mathrm{Si}$ module for a day of month January for BiSPVT system integrated to roof, with duct.

Table 2. Maximum room temperature, module temperature and efficiency for different packing factors and types of PV module (with duct)

\begin{tabular}{|c|c|c|c|c|c|c|c|c|c|c|}
\hline \multirow{3}{*}{ PV modules } & \multicolumn{10}{|c|}{ Packing factor } \\
\hline & \multirow{2}{*}{$\frac{\mathbf{0}}{T_{r}\left({ }^{\circ} \mathrm{C}\right)}$} & \multicolumn{3}{|c|}{0.42} & \multicolumn{3}{|c|}{0.62} & \multicolumn{3}{|c|}{0.83} \\
\hline & & $T_{c}\left({ }^{\circ} C\right)$ & $\eta(\%)$ & $T_{r}\left({ }^{\circ} C\right)$ & $T_{c}\left({ }^{\circ} C\right)$ & $\eta(\%)$ & $T_{r}\left({ }^{\circ} \mathrm{C}\right)$ & $T_{c}\left({ }^{\circ} C\right)$ & $\eta(\%)$ & $T_{r}\left({ }^{\circ} C\right)$ \\
\hline $\mathrm{m}-\mathrm{Si}$ & 35.00 & 24.00 & 13.60 & 26.24 & 31.56 & 13.10 & 22.00 & 40.00 & 12.80 & 17.65 \\
\hline p- Si & 35.00 & 25.00 & 11.60 & 26.51 & 33.00 & 11.24 & 22.33 & 41.00 & 10.86 & 18.00 \\
\hline a Si & 35.00 & 28.00 & 6.20 & 27.30 & 36.00 & 6.10 & 23.10 & 44.00 & 6.00 & 19.00 \\
\hline $\mathrm{CdTe}$ & 35.00 & 28.00 & 6.90 & 27.20 & 35.46 & 6.80 & 23.00 & 43.58 & 6.60 & 19.00 \\
\hline CIGS & 35.00 & 27.00 & 8.10 & 27.00 & 34.50 & 7.80 & 23.00 & 43.00 & 7.50 & 18.40 \\
\hline HIT & 35.00 & 22.00 & 17.20 & 26.00 & 29.00 & 16.70 & 21.55 & 17.15 & 16.30 & 17.15 \\
\hline
\end{tabular}

It is found that the room temperature is maximum in a- Si, CdTe and Copper Indium Gallium Selenide (CIGS) PV modules. As the packing factor decreases from $0.83-$ 0.42 , the room temperature increases from 19.00-27.00 ${ }^{\circ} \mathrm{C}$ and $21.00-29.00{ }^{\circ} \mathrm{C}$ in with and without duct respectively. The rise in room temperature for both systems is $8.0{ }^{\circ} \mathrm{C}$. It also seems that maximum room temperature is 35.00 and $58.00{ }^{\circ} \mathrm{C}$ in zero packing factor (double glazing) in with and without duct respectively. This is valuable only for heating point of view.

\section{Conclusions}

On the basis of present study, the summary of the study is as follows: 
- $\quad$ Forced circulation of air through duct decreases the module temperature in BiSPVT system with duct.

- Indirect heat gain in room due to presence of roof decreases the room temperature in BiSPVT system with duct.

- Decrease in packing factor from 0.83 to 0.42 , decreases the module temperature by $16{ }^{\circ} \mathrm{C}$, increase its efficiency by $0.8 \%$ and room temperature by $8.6{ }^{\circ} \mathrm{C}$ in BiSPVT system integrated to roof with duct.

\section{References}

1. Bloem, J.J., 2008. Evaluation of a PV- integrated building application in a well-controlled outdoor test environment. Building and Environment 43, 205-216.

2. Zogou, O., Stapountzis, H., 2011. Energy analysis of an improved concept of integrated PV panels in an office building in central Greece. Applied Energy 88, 853- 866.

3. Yoon, J.H.,.Song, J.H., Lee, S.J., 2011. Practical application of building integrated photovoltaic (BIPV) system using transparent amorphous silicon thin-film PV module. Solar Energy 85, 723- 733.

4. Jones, A.D., Underwood, C.P., 2001. A thermal model for photovoltaic systems. Solar Energy 70 (4), 349-359.

5. Zondag, H.A., de Vries, D.W., van Helden, W.G.J., van Zolengen, R.J.C., Steenhoven, A.A., 2003. The yield of different combined PV-thermal collector designs. Solar Energy 74 (3), 253-269.

6. Chow, T.T., 2003. Performance analysis of photovoltaic- thermal collector by explicit dynamic model. Solar Energy 75, 143-152.

7. Ji, J., Han, j., Chow, T.T., Yi, H., Lu, J., He, W., Sun, W., 2006. Effect of fluid flow and packing factor on energy performance of a wall- mounted hybrid photovoltaic/water heating collector system. Energy and Buildings 38, 1380-1387.

8. Makrides, G., Zinsser, B., Norton, M., Georghiou, G.E., 2010. Schubert M, Werner JH. Potential of photovoltaic systems in countries with high solar irradiation. Renewable and Sustainable Energy Reviews 14, 754-762.

9. Ordenes, M., Marinoski, D.L., Braun, P., Ruther, R., 2007. The impact of building-integrated photovoltaics on the energy demand of multi-family dwellings in Brazil. Energy and Buildings 39, 629642.

10. Goetzberger, A., 2002. Photovoltaic material, history, status and outlook. Materials Science and Engineering 40, 1- 46.

11. Dubey, S., Sandhu, G.S., Tiwari, G.N., 2009. Analytical expression for electrical efficiency of PV/ T hybrid air collector. Applied Energy 86, 697-705.

12. Agrawal, B., Tiwari, G.N., 2010. Optimizing the energy and exergy of building integrated photovoltaic thermal (BIPVT) systems under cold climatic conditions. Applied Energy 87, 417- 426 